\title{
Between Diplomacy and Letters: A Sketch of Manuel de Oliveira Lima's Search for a Brazilian Identity
}

\author{
Joshua Alma ENSLEN*
}

"A história varia segundo o ponto-de-vista de quem a escreve."

Alexandre Gusmão, Secretário d'El Rei

\begin{abstract}
Manuel de Oliveira Lima as an important diplomat of the First Republic in Brazil reflects on an individual, national, and universal plane the convergence of politics and literature. His writing demonstrates an explicit attempt to construct a national identity that emanates not only between literature and diplomacy, but also between the personal and the historical, as well as, the foreign and the national. This paper analyzes brief examples of his criticism, personal correspondence, and fiction that demonstrate the convergence of these fields.
\end{abstract}

KEYWORDS: Manuel de Oliveira Lima; Brazilian national identity; literature and diplomacy.

Throughout modern history, certain enfranchised figures like the litterateur-diplomat have emerged in relief expressing the power to serve as interlocutors between the potentially distant poles of politics and literature. These men, empowered by writing, have moderated the construction of national identity by way of convergence. According to $\mathrm{H}$ omi $\mathrm{K}$ Bhabha, it is expressly from the union of politics and literature that the symbolic modern nation manifests itself:

Nations, like narrative, lose their origins in the myths of time and only fully realize their horizons in the mind's eye. Such an 
image of the nation - or narration - might seem impossibly romantic and excessively metaphorical, but it is from those traditions of political thought and literary language that the nation emerges as a powerful historical idea in the west. An idea whose cultural compulsion lies in the impossible unity of the nation as a symbolic force. ${ }^{1}$

In late $19^{\text {th }}$ century Brazil, there may be no better example of an individual who emblematizes this ephemeral politico-cultural travessia than Manuel de Oliveira Lima (1867-1928). Doubly empowered by the nation, not only through writing but also through diplomacy, Oliveira Lima represents the conflux of symbolic forces that constitute a burgeoning national identity as the Brazilian First Republic (1889-1930) began to take shape. In this analysis I will frame the complex politico-cultural matrix that incorporates the mediatory movements of this Latin American diplomat as he negotiated the literary spaces within his nation and others by analyzing drawing connections between his literary criticism, personal correspondence, and fiction.

As Oliveira Lima expressly seeks to locate the nexus of Brazil's own "impossible unity" (as Bhabha termed it) he plots a navigable course that we might follow. By analyzing his writing we can explore his conceptualization of Brazilian identity while at the same time open the way for an attempt at configuring the significance of being a litterateur-diplomat at this important historical moment in Brazilian national history. Demonstrating a similar focus in his writing as many others in Latin America of his time, Oliveira Lima's writing represents an attempt to reconstructs his nation's relationship with the old metropolis in a new light. While at the same time that Oliveira Lima creates literary work that reflects his personal links with Portugal, he also constructs Brazil as a nation only capable of developing successfully in politics and culture as long as it remains faithful to its Portuguese roots.

The presence of the litterateur-diplomat in Latin America as a vehicle for shaping national identity is unmistakable. Brazil is no exception. Similar to Chile's Pablo Neruda and Gabriela Mistral or M exico's Octavio Paz, ${ }^{2}$ Brazil has its own impressive 
list of influential literary figures that have played important roles in diplomacy, conducting official negotiations between Brazil and other nations. Manuel de Oliveira Lima like Joaquim N abuco, Graça Aranha, João Guimarães Rosa, and poets like João Cabral de $M$ elo $N$ eto and Vinicius de M orais, to name but a few, are all part of a long tradition of Brazilian writers utilized by the State as representatives in the international arena. ${ }^{3}$ Teresa $M$ alatian in a study on the personal correspondence between the Brazilian writer M achado de Assis and Oliveira Lima, comments on the relationship between literature and diplomacy as she showed how it reflected collective and individual power arrangements within the newly formed Academia Brasileira de Letras $(A B L)$.

Essa relação entre diplomacia e letras constitui um aspecto pouco explorado pela historiografia e nesse sentido as cartas em análise fornecem elementos para sua maior compreensão, seja no tocante ao ingresso de diplomatas na instituição, seja na temática de obras publicadas. Enfim, elucidam relaçốes de poder ali. $^{4}$

Just as Malatian explored the power relations found between literature and diplomacy during the first years of the $A B L, I$ propose in like manner to delineate three distinct yet interconnected ways that Oliveira Lima, as an empowered member of the Brazilian intelligentsia, ${ }^{5}$ endeavored to construct national identity around the time of the First Republic. Being at once both cosmopolitan ${ }^{6}$ and Brazilian, writer and diplomat, Latin American and citizen of the world, Oliveira Lima transformed his life, his work, and even his own death into a symbolic profound expression of individual, nation, and world.

Oliveira Lima was born in Recife, Pernambuco on the $25^{\text {th }}$ of December in 1867.7 As a pernambucano de nascença but with a Portuguese father, Oliveira Lima would spend his formative years in Portugal and, as a result, he would begin to articulate his own personal identity as a duplicitous invention. He benefited from the duality of a childhood lived both in Portugal and Pernambuco and Oliveira Lima's education in the old metropolis 
combined in a unique way with his acute and permanent sense of brasileiridade. Alexandre José Barbosa Lima Sobrinho, in his piece "Oliveira Lima: Sua Vida e Sua Obra," explains how this union was manifested in his youth:

A vida em Portugal, as amizades no colégio e na academia, o interesse natural pelos acontecimentos que o envolviam, a sugestão dos planos do futuro, quando tão distanciado se achava do meio e das possibilidades brasileiras, a freqüentação das assembléias políticas, nada Ihe deu a idéia de prender-se realmente a Portugal. Ao contrário viveu sempre como quem não pensasse senão em regressar à terra do nascimento. Sua aprendizagem diplomática se fazia na Legação do Brasil e não no Ministério do Exterior de Portugal. ${ }^{8}$

Accordingly, the dual nature of his upbringing being both Portuguese and Brazilian reflected a unique sense of exile. This exile we might define as being in propria persona Brazilian but in locus seemingly always somewhere else. As Oliveira Lima would come to terms with a youth spent not only physically but imaginatively between Portugal and Brazil, this exile would echo throughout his career in various incarnations of which literature would represent only one.

In Oliveira Lima's theatrical comedy Secretário d'El Rei, exile is represented metaphorically by the protagonist Alexandre Gusmão. He, like Oliveira Lima, finds himself estranged from Brazil as a secretary in the courts of the Portuguese metropolis. There, in Portugal attending to the business of King Dom J oão V, Gusmão becomes caught up in a love triangle which, in the words of M achado de Assis, "characterizes well the capital of the kingdom, with the masks of nocturnal lovers, the jealousy of his lady, the encounter of vagrants, furled capes, brandished swords, [and] deaths." ${ }^{\prime \prime}$ In this play, even though Gusmão's love for D ona Luz is ultimately frustrated he wishes her well on her move to Brazil as she is married to his rival, Dom Fernando. Upon arriving at their new home and in order to show their respect to Gusmão's courteous act, Dom Fernando and Dona Luz promise to tirelessly "work for the progress of Brazil." ${ }^{10}$ Yet, they were not the only ones interested in such a project. 
Reviewed by Machado de Assis in 1904, this theatrical drama (Oliveira Lima's only fictional work) was praised for its “... national spirit that assures [Oliveira Lima] an eminent place in the historical and political literature of our land."11 Recognizing not only the dual presence of history and politics within the work but also the duality of the plays locus, existing between a real Portugal and (as we will see) a mythical Brazil, Machado de Assis writes: "With reason the author calls his Secretário d'El Rei a national play, although the action takes place in our old metropolis in those years of $\mathrm{D}$. João $\mathrm{V}$. It is doubly national, in relation to the society of Lisbon."12 From Lisbon, where Gusmão also finds himself being 'doubly national,' he relates, much like the poet-narrator of Gonçalves Dias' Canção do exílio, "an image of the nation" that is "impossibly romantic and excessively metaphorical:" ${ }^{13}$

Lá podereis dilatar o peito, encher os pulmões, respirar livres, em paz, na plena selva virgem, ao abrigo das tentações políticas e dos enredos das tertúlias. Nada há de melhor para a alma do que essas imersões na Natureza. Retemperam-Ihe o vigor, purificamIhe a substancia... Vereis se vos engano, se existe nada mais belo do que aquela terra de encantos. Tudo alí é formoso, e é grande. As colinas são montanhas, as árvores gigantes, os rios mares, os campos solidões ou antes oásis sem fim. Dá gosto viver debaixo daquele céu azul, naquela atmosfera transparente, sobre aquele solo privilegiado. ${ }^{14}$

In this description, Brazil is portrayed as an Edenic utopia being at once powerful, gigantic, and peaceful. It is a paradise waiting to be discovered. However, of all the images evoked in this mythical description of Brazil, there is one crucial element that is most notably absent. In Gusmão's Brazil, there are no people. There are only 'hills that are mountains' and 'rivers that are seas.' Indeed, in this Brazil, there are no Brazilians.

These bucolic descriptions depict an eternal nation that serves as a primordial locus in which history is waiting to be created. Thus just as Gusmão finds himself being in propria persona a Brazilian, but in locus somewhere else, so has he displaced the one indispensable element needed to establish a 
nation: its people. This explicit concealment of the Brazilian by a gigantic Edenic nation is an imaginary narrative capable not only of catachrestic historical reinvention, but also of "accommodat[ing] an entire citizenry"15 in the process. Or rather, this mythical construction dispensing with the necessity to 'accommodate' goes one step further; it practically elides the existence of an entire citizenry in order to potentiate a Brazil at the point of genesis. It is this type of narrative, "hav[ing] a symbolic or ideological rather than a realistic plausibility," ${ }^{16}$ that Oliveira Lima, like other writers of the Romantic period, would employ to fill in the gaps associated with "the novelty, or as some would say, the immaturity of post-independence history."

Although Secretário d'El Rei may be Oliveira Lima's only published fictional effort, his participation in the world of Brazilian fiction is by no means limited to this anomalous work. Oliveira Lima, besides being a prolific historian producing a substantial ouevre, was also an important literary critic. His criticism, coupled with that by others of the Brazilian intelligentsia, bore directly on the construction of national identity. Chief among these critics was of course Machado de Assis who, in his influential essay "Instinto de Nacionalidade" (1873), communicates the importance of criticism to the development of a national literature. For M achado de Assis, the greatest impediment to the emergence of such a literature was an underdeveloped criticism:

A falta de uma crítica assim é um dos maiores males de que padece a nossa literatura; é mister que a análise corrija ou anime a invenção, que os pontos de doutrina e de história se investiguem, que as belezas se estudem, que os senões se apontem, que o gosto se apure e eduque, e se desenvolva e caminhe aos al tos destinos que a esperam. ${ }^{18}$

According to Machado, it was only in this way that a national literature could reform itself and take a definite shape because, as a result, it would have the power to direct Brazil towards its 'high destinies.' Thus, echoing in no small degree the symbolism of Romantic narratives, M achado de Assis suggests in "Instinto de 
Nacionalidade" that a successful literary criticism could help to project future ideals. Such a view of criticism, also inextricably linked to history and politics by evoking a politics of literature (just as Machado de Assis posited about Secretário d'El Rei), was crucial to the nascent self-concept of Brazil as a newly independent nation on its way to becoming a Republic.

As an example of Oliveira Lima's criticism in which there is an obvious effort to converge the political with the literary, we might note a simple preface written for the 1916 edition of Afonso Henrique Lima Barreto's influential novel Triste Fim de Policarpo Quaresma. In this short piece, Oliveira Lima provides a brief yet provocative panorama of the then current literature. He criticizes in like fashion the facility of Graça Aranha's Canaã and the philosophical and stylistic dependency of Aluísio Azevedo's 0 M ulato. ${ }^{19} Y$ et, on the other hand, by praising Lima Barreto's work as inhabiting a distinctly original space shared by certain works like Manuel de Almeida's M emórias de um Sargento de M ilícias, he proposes that Triste Fim de Policarpo Quaresma represents "in the genre of the novel... a spirit in which a social sense aligns itself with the picturesque."

Considering this alignment of 'the picturesque' with the 'social' as being analogous with the convergence of literature and politics (the picturesque being the symbolic 'spiritual' illustration of the real and the 'real' of the novel reflecting the immediate social and political problems of the time), it is not difficult to associate this review with a national project. Consequently, Oliveira Lima asserts that this felicitous union between the social and picturesque that brings into being Major Quaresma is possible not only within the pages of the book but also in the real world. Major Quaresma, according to Oliveira Lima, is a representation of "the famous benevolence of the Brazilian soul [that] will turn itself into reality." ${ }^{21}$ National symbols, representing reality's hope yet remaining forever just out of reality's grasp, have the potential to unify as they become the expression of a single "Brazilian soul." Accordingly, Oliveira Lima celebrates the protagonist of Lima Barreto's novel by proclaiming that the visionary "Major Quaresma will live in tradition, as a national Don Quixote." 
In this way one more association is possible between this review and Secretário d'El Rei. While omitting in his theatrical comedy the Brazilian in propria persona in favor of a mythical Edenic locus wherein those destined there from the metropolis might invent their own New World, Oliveira Lima in this review constructs the Brazilian progeny that will result from the transplanted couple's union. And thus, the Edenic yet descriptively uninhabited Brazilian utopia of Oliveira Lima's Secretário d'El Rei begins to be populated by figures like Major Quaresma who become national symbols transformed from mythical dust into literary flesh by the intelligentsia. Iterated in prognostic fashion as the offspring not just of the picturesque and the social but also of the literary and the political, Major Quaresma, like Almeida's Leonardo Filho, is transfigured as a national symbol in the Brazilian literary imaginary.

These specific examples of Oliveira Lima's literary work represent a conscientious effort to concretize nascent Brazilian identity in two distinct, yet not entirely mutually exclusive ways: literary criticism and fiction. Thus, from Oliveira Lima's exogenous vantage point as a diplomat, he was in a privileged position to articulate a vision of Brazil that would help frame such an identity. Furthermore, a curious parallel emerges between his writing and his life and Oliveira Lima's personal attempts to encounter his own brasileiridade echo on a national plane. By filling in the gaps between his propria persona as a Brazilian and his estranged locus, his criticism and fiction merge constructed as a mythical, integral, and unified whole that resonates between the dualities of not only literature and diplomacy, but also the personal and the historical, as well as, the foreign and the national.

If this review and play show any evidence of an autobiographical resemblance found in Alexandre Gusmão or even in Major Quaresma with Oliveira Lima, it is not without an equal correlation that Gilberto Freyre in Oliveira Lima: Don Quixote Gordo (1968) observes that Oliveira Lima had a perplexing personality and "tended to be romantic, idealist, and, at times, even insensitive." ${ }^{23}$ In Freyre's book composed mainly of conference addresses and other correspondence between Oliveira 
Lima and the author, Freyre refers to the emphasis placed on tracing through history the moments, movements, and literary works that give Brazil its own national character. In a conversation that Freyre had with Oliveira Lima while they both lived in the United States (Freyre at college and Oliveira Lima at work in W ashington), he quotes the diplomat as having stated:

É preciso fixar como Varnhagem uma atenção absorvente no conhecimento do passado pátrio; conservar como M agalhães um interesse profundo na evolução da expressão poética e filosófica da literatura de que era ornamento; prender-se como Ourem ao desenvolvimento e notar as tendências da legislação nacional; identificar-se como Penedo com o desdobrar dos recursos, a florescência da economia e o prestigio do nome brasileiro - para se conservar ininterrupto o circuito e manter-se constante a correspondência não entre agente e o governo, mas, o que é bem mais custoso, entre o rebento transplantado e o tronco originário... não esquecem seus horizontes, não alheiam seus corações e não abdicam seus origens. ${ }^{24}$

Oliveira Lima, as a diplomat, found himself interacting with not only the cultural producers, but also the national and international political figures of the time. As a result, it is from this perspective that he is configured as a member of a distinct group of intelligentsia from which he believed a successful Brazilian politico-cultural self-concept might be conveyed.

The language in this quote depicts an almost perfect metaphor symbolizing the importance of the diplomat to the formation of this concept. Reminiscent of how Christ's lineage is linked by the writers of the New Testament to King David and subsequently to Abraham the father of the Israelite nation in order to give credence to the emerging Christian religion, Oliveira Lima recollects the language from one of the most important foundational texts in the Western world. ${ }^{25}$ Yet, rather in a circular fashion instead of a chronological one, this genealogy of the litterateur-diplomat ${ }^{26}$ traces the contours necessary to circumscribe a historically 'new' Brazilian identity 
that must be, as he proposes, linked to the 'old' in order to gain direct authorization to enter into the dialogue of individuated 'mature' nations.

This relationship between the 'old' and 'new,' simultaneously autobiographical, national, and universal, constitutes a canonical move by Oliveira Lima to define who on an individual plane possesses the power to constructs the parameters of a national identity. These prophets of the new Brazilian nation are none other than its very own diplomats: Varnhagem, M agalhães, O urem, and Penedo. And Oliveira Lima expresses the national commandments brought down from an intellectual Mount that will bring to fruition such a project: Write history, poetry, and philosophy; Create an economy that will reflect the "prestige of the Brazilian name;" and Secure a government that will do likewise.

In addition, while implying his own inclusion within this lineage constructed between "agent and government," and between the Old and N ew Worlds, Oliveira Lima also enters into an interesting intertextual dialogue with at least one other contemporaneous Latin American writer. There is a distinct contrast we might draw between Oliveira Lima's idea of genealogical linkage with Europe and Jose Martí's emphasis on rupture embodied among other ways in the metaphor of the trunk. In his influential essay Nuestra América written in 1891 Martí writes:

La historia de América, de los incas acá, ha de enseñarse al dedillo, aunque no se enseñe la de los arcontes de Grecia. N uestra Grecia es preferible a la Grecia que no es nuestra. Nos es más necesaria. Los políticos nacionales han de reemplazar a los políticos exóticos. Injértese en nuestras repúblicas el mundo; pero el tronco ha de ser el de nuestras repúblicas. Y calle el pedante vencido; que no hay patria en que pueda tener el hombre más orgullo que en nuestras dolorosas repúblicas americanas. ${ }^{27}$

In Nuestra America, although he is attempting a rupture with "that [which] is not ours," Martí represents the "typical irony of writing (in) America" ${ }^{28}$ as he conveys a "history of 
America" that is still perhaps judged by European paradigms. When he states: "Our Greece is preferable to the Greece that is not ours," Incan history inadvertently becomes a mere New World reflection of Greek History instead of standing in its own right. In this way a contrast as well as a parallel emerges between the authors. As Martí demonstrated how "[s] uccessive generations may deny literary resemblances to the point that denial itself constitutes a resemblance," ${ }^{29}$ Oliveira Lima to the contrary, seems to be open to this resemblance. Thus, while both writers' nation-building projects share similar goals and even dependencies, their approaches are formed from opposing points of reference not only intellectually but also geographically within a single Latin American spectrum. As Jose Martí intellectually had colonized the indigenous space while the "Indian circled about... in silent wonder," ${ }^{30}$ Oliveira Lima's perspective proves no less problematic by overtly neglecting other peripheral cultural discourses.

In this way, demonstrating some of the incoherencies inherent in traversing the complex politico-cultural matrix of Latin American national identity, Oliveira Lima emphasizes the importance of mutual dialogue with the old metropolis. Whereas Martí claims "the trunk must be our own," Oliveira Lima proposes Brazil must "maintain uninterrupted the circuit... between transplanted son and trunk of origin." Oliveira Lima's movement reflects a coming-to-terms with the dominant influence of European history and culture on the formation of Brazilian national identity. Furthermore, by proclaiming: "do not forget your horizons, do not estrange your hearts and do not abdicate your origins," the nation-state (an idea emanating explicitly from Europe and not from an indigenous history) and likewise Brazil becomes for Oliveira Lima a "symbolic force" that resides at a mythical conflux of past, present, and future. This canonical construction erected from the vestiges of colonialism is realized at the horizon of the eternal present where the future could converge with the roots of the past perpetually elevating Portugal's "transplanted son" to its 'royal' place within the constellation of modern nationhood.

Of course, once having reached a secure distance from 
independence and the birth of the First Republic, the fields of literature and politics would begin to diverge. Demanding greater efforts on the part of the litterateur-diplomat to successfully navigate the opposing fields, this new relationship would at times create if not greater diplomacy certainly greater literature which would manifest perhaps a more universal, mature, and profound sense of Brazilian identity. Such, it might be argued, would at least be the case of the litterateur-diplomat J oão Guimarães Rosa. But, this fact in no way lessens the pioneering efforts of litterateur-diplomats from the First Republic like Oliveira Lima. ${ }^{31}$ It was necessary in this period that literature and diplomacy came together in Brazil in a more pronounced fashion due to the improvisational nature of the newly independent nations. Thus, $M$ anuel de Oliveira Lima may be recognized as one of the true precursors to some of the most important figures in Brazilian literature. $\mathrm{He}$, as a litterateur-diplomat like João Guimarães Rosa and as a historian and sociologist like his protégé Gilberto Freyre, has an important legacy in the development of Brazilian national literature and consequently in the construction of national identity.

As a polyglot, diplomat, playwright, historian and critic prolific like only few others, Oliveira Lima, in symbolic fashion, united the three levels of his life and work - the individual, national, and the universal - into an important symbolic representation of Brazilian culture. The simple phrase on his headstone "Aqui jaz um amigo dos livros" 32 belies the importance of Oliveira Lima to a national project. Yet, this anonymous epitaph, as a double reduction of his life into text, not only marks the spot where his body lies, but signifies the symbolic importance of words to the one who rests there as well as to the nation he represented. In the same way that Oliveira Lima's life is reduced to this simple phrase, the consolidation of a complex and diverse politico-cultural and historical reality into a single Brazilian idea could only be potentiated by way of the written word. Furthermore, as Oliveira Lima's body rests in foreign soil, he seems to posthumously suggest that Brazilian literature in order to perpetuate its endless return had to project itself back across its borders in order to stake its claim among the 
metropolises old and new. Reflecting the autobiographical as an intrinsic part of the national and subsequently universal, Oliveira Lima's writing reminds us of his protagonist's Alexandre Gusmão's closing lines: "A história varia segundo o ponto-devista de quem a escreve."

ENSLEN, Joshua Alma. Entre diplomacia e letras: um esboço sobre a busca de Manuel de Oliveira Lima pela identidade brasileira. História, São Paulo, v.24, n.1, p.243-259, 2005.

RESUMO: Manuel de Oliveira Lima, como um importante diplomata da Primeira República no Brasil, reflete nos planos individual, nacional e universal a convergência da política e da literatura. Seus escritos demonstram uma tentativa explícita de construir uma identidade nacional que emana não apenas da literatura e da diplomacia, mas também do pessoal e do histórico, assim como do estrangeiro e do nacional. Este artigo analisa alguns exemplos de seu criticismo, correspondência pessoal e ficção para demonstrar a convergência entre estes campos.

PALAVRAS-CHAVE: Manuel de Oliveira Lima; identidade nacional brasileira; literatura e diplomacia.

\section{NOTAS}

\footnotetext{
* Department of Romance Languages - University of Georgia, mailing address: 370C Gilbert Hall, Athens GA 30605, USA. e-mail: enslenja@uga.edu. All translations are my own unless otherwise noted.

${ }^{1}$ See page 1 of Bhabha's introduction to Nation and Narration. New York: Routledge and Keegan Paul, 1990.

${ }^{2}$ All three of these litterateur-diplomats were Nobel Prize laureates: Mistral (1945), Neruda (1971), and Paz (1990). Information taken from http://nobelprize.org

${ }^{3}$ This tradition between writing and diplomacy continues in one form or the other to this day with writers like João Almino, the current Brazilian Ambassador to the US in Miami and Jabuti laureate.

4 "This relation between diplomacy and letters constitutes a scarcely explored aspect of historiography and in this sense the letters under analysis furnish
} 
elements for its greater comprehension, whether it is touching the ingress of diplomats into the Academy, whether it is on the thematic of literature published. In the end, the works elucidate power relations therein contained." Quoted from Teresa Malatian's "Diplomacia e Letras na correspondência acadêmica: Machado de Assis e Oliveira Lima". Estudos Históricos, Rio de Janeiro, v.13, n.24, p.377-392, 1999.

${ }_{5}^{5}$ The term intelligentsia is defined by Karl Mannheim in Ideology and Utopia New York, London: Routledge, 1991, when he states that "In every society there are social groups whose special task it is to provide an interpretation of the world for that society. We call these the 'intelligentsia' (9).

${ }^{6}$ Freyre states on page 102 of Oliveira Lima, Don Quixote Gordo (Pernambuco: UFP, 1968): Para ele, quase místico como era, do pacifismo, ser cosmopolita era superar aquele etnocentrismo e aquele nacionalismo inimigos da convivência construtivamente pacifica entre nações e entre homens. Nunca se envergonhou do seu cosmopolitismo. \{For him, almost a mystic as he was, of pacificism, to be cosmopolitan was to overcome that ethnocentrism and that nationalism enemies of a constructively pacific coexistence between nations and between men. He was never embarrassed by his cosmopolitanism.

7 Information taken from page 27 of Oliveira Lima, uma biografia (Recife: Instituto Arqueológico, Histórico e Geográfico Pernambucano, 1976) by Fernando da Cruz Gouvêa.

8 "Life in Portugal, the friendships in school and in the academy, the natural interest for events all around him, the promise of future plans, when even at such a distance he found himself from the path and from the possibilities of Brazil, the attendance of political assemblies, nothing gave him the idea to bind himself to Portugal. To the contrary he always lived as one who only thought in returning to the land of his birth. His diplomatic apprenticeship was done in the Brazilian Legation and not in Portugal's Foreign Ministry." Quote taken from page 18 of Alexandre José Barbosa Lima Sobrinho's "Oliveira Lima: Sua Vida e Sua Obra" (Ed. Barbosa Lima Sobrinho. Oliveira Lima/ Obra Seleta (Coleção Centenário). Rio: Instituto Nacional do Livro, 1971, p.17-131.

${ }^{9}$ The original reads: “A aventura que constitue a ação é do lugar e do tempo; as pessoas e os atos que figuram nela caracterizam bem a capital dos reinos, com a mascara dos namorados noturnos, a gelosia de sua dama, o encontro de vadios, capas enroladas, espadas nuas, mortos, feridos, a ronda, todo o cerimonial de uma aventura daquelas." (Machado de Assis, Joaquim Maria. "Oliveira Lima: Secretário d'El Rei" Obra Completa, v.III. Ed. Afrânio Coutinho. Rio: Editora José Aguilar Ltda., 1962, p.937-938.

${ }^{10}$ The original reads: "Trabalhar pelo progresso do Brasil será o nosso único meio de corresponder a vossa generosa estima e mostrar quanto nós lembraremos de vós, e com quantas saudades" (1016). (Oliveira Lima, Manuel 
de. Secretário D'El Rei. Ed. Barbosa Lima Sobrinho. Oliveira Lima/ Obra Seleta (Coleção Centenário). Rio: Instituto Nacional do Livro, 1971, p.998-1016.

${ }^{11}$ From Machado de Assis' "Oliveira Lima: Secretário d'El Rei” page 938.

${ }^{12}$ The original reads: “...espírito nacional que [a Oliveira Lima] assegura lugar eminente na literatura histórica e política da nossa terra." and "Com razão chama o autor ao seu Secretário d'El Rei uma peça nacional, embora a ação se passe na nossa antiga metrópole, por aqueles anos de D. João V. É duas vezes nacional, em relação à sociedade de Lisboa.” Idem, p.937.

${ }^{13}$ See quote from Bhabha first paragraph.

14 "There you can expand your chest, fill your lungs, breathe freely, in peace, in the purely virgin forest, sheltered from political temptations and from the plots of the assemblies. There is nothing better for the soul than those immersions in Nature. They renew your vigor, purify your substance... You will see if I mislead you, if there exists nothing more beautiful than that land of enchantment. Everything there is beautiful, and it is grand. The hills are mountains, the trees giants, the rivers seas, the fields wildernesses or even oasis without end. It is pleasing to live underneath that blue heaven, in that transparent atmosphere, above that privileged soil." From page 1015 of Oliveira Lima's Secretário d'El Rei.

${ }^{15}$ Taken from page 75 of Sommer's "Irresistible romance: the foundational fictions of Latin America" (Nation and Narration. Ed. Homi K Bhabha. New York: Routledge and Keegan Paul, 1990).

${ }^{16}$ Taken from page 13 of Richard Chase's The American Novel and its Tradition (Maltimore,MD: Johns Hopkins UP, 1983).

17 "To be more precise, the novelty or, as some would say, the immaturity of post-independence history would bring it close to Veyne's position. In the epistemological gaps that the non-science of history leaves open, narrators could project an ideal future." Taken from page 76 of Sommer's "Irresistible romance: the foundational fictions of Latin America" (Nation and Narration. Ed. Homi K Bhabha. New York: Routledge and Keegan Paul, 1990).

18 "The lack of criticism thus is one of the greatest ills that our literature suffers; it is necessary that analysis corrects or stimulates invention, that points of doctrine and of history are investigated, that beauties are studied, that objections are noted, that taste is refined and educated, and that [our literature] develops and makes way towards the high destinies that [our criticism] expects." See page 804 of Machado de Assis' "Instinto de Nacionalidade" (Obra Completa, v.III. Ed. Afrânio Coutinho. Rio: Editora José Aguilar Ltda., 1962, p.801-809).

${ }^{19}$ Both Graça Aranha and Aluísio de Azevedo, besides being writers, were also diplomats.

20 See Oliveira Lima's "Prefácio: Policarpo Quaresma" (Triste fim de Policarpo Quaresma. Rio de Janeiro: Tecnoprint SA, 1980). The original reads: “...no 
gênero romance, da mais prometedora vocação da geração nova, espírito no qual se alia ao senso do pitoresco o senso social" p.8.

${ }^{21}$ Idem, p.8. The original reads: "...a bondade famosa da alma brasileira se tornará uma realidade."

${ }^{22}$ Idem, p.6. Mixing the literary with the literal, and thus the symbolic with the real, by positing how the literary charater 'o marechal de ferro' would have acted had he literally read Cervantes, the original reads: "Entretanto o Major Quaresma viverá na tradição, como um Dom Quixote nacional. Ambos são tipos de optimistas incuráveis, porque acreditam que os males sociais e sofrimentos humanos podem ser curados pela mais simples e ao mesmo tempo mais difícil das terapêuticas, que é a aplicação da justiça... Um levou sovas por querer proteger os fracos; o outro foi fuzilado por querer na sua bondade salvar os inocentes. Visionários ambos: assim tratou o marechal de ferro o seu amigo Quaresma e trataria Dom Quixote, se houvesse lido Cervantes.

${ }^{23}$ The original on page 55 reads: Não deixava de influir sôbre o íntimo que tendia a ser romântico, idealista, e, por vezes, até insensato." FREYRE, Gilberto. Oliveira Lima: Don Quixote Gordo. Pernambuco: UFP, 1968.

24 "It is necessary to establish as Varnhagem an engrossing attention to the recognition of the nation's past; to conserve like Magalhães a profound interest in the evolution of the poetic and philosophical expression of literature of which it was an ornament; to attach oneself as Ourem to development and to note the tendencies of the national legislation; to identify oneself as did Penedo with the unfolding of resources, the florescence of the economy and the prestige of the Brazilian name - in order to maintain uninterrupted the circuit and to make constant the correspondence not between agent and government, but, what is more exacting, between transplanted son and trunk of origin (...) do not forget your horizons, do not estrange your hearts and do not abdicate your origins". Idem, p.107.

${ }^{25}$ Matthew 1.1-17: THE book of the generation of Jesus Christ, the son of David, the son of Abraham. Abraham begat Isaac; and Isaac begat Jacob; and Jacob begat Judas and his brethren; And Judas begat Phares and Zara of Thamar; and Phares begat Esrom; and Esrom begat Aram; And Aram begat Aminadab; and Aminadab begat Naasson; and Naasson begat Salmon... [etcetera]; And Jacob begat Joseph the husband of Mary, of whom was born Jesus, who is called Christ.

${ }^{26}$ All names mentioned are those of important diplomats.

${ }^{27}$ MARTÍ, Jose. "Nuestra América." In:__. Páginas Escogidas. Ed. Alfonso M Escudero. Madrid: Coleccion Austral, 1970, p.117-124. "The history of America, from the Incas to the present, must be taught until it is known by heart, even if the Archons of the Greeks go by the board. Our Greece must take priority over the Greece that is not ours: we need it more. Nationalist statesmen must replace cosmopolitan statesmen. Let the world be grafted on 
our republics; but the trunk must be our own. And let the vanquished pedant hold his tongue: for there are no lands in which a man can take greater pride than in our long-suffering American republics." This translation of "Our America" is by Juan de Onís found in The America of José Martí New York: The Noonday, 1953.

${ }^{28}$ Taken from page 73 of Sommer's "Irresistible romance: the foundational fictions of Latin America" (Nation and Narration. Ed. Homi K Bhabha. New York: Routledge and Keegan Paul, 1990).

${ }^{29}$ Idem.

${ }^{30}$ See footnote 27

${ }^{31}$ In her article "Diplomacia e Letras na correspondência acadêmica: Machado de Assis e Oliveira Lima," Malatian also observes: "É, contudo, nas eleições acadêmicas que se encontram informações ainda mais significativas acerca da intersecção dos campos sociais da diplomacia e das letras no espaço de sociabilidade da ABL. Desde sua fundação a $\mathrm{ABL}$ abrigava número significativo de diplomatas, contando entre os fundadores Aluísio de Azevedo, Domício da Gama, Graça Aranha, Luís Guimarães Júnior, Magalhães de Azeredo, Oliveira Lima, Salvador de Mendonça."

32 Oliveira Lima's last Will and Testament reads: "Como epitáfio, escolho somente este: Aqui jaz um amigo dos livros, sem indicação de nome. Estimaria sobremodo que a minha mulher repousasse perto de mim. Também quero que nenhuma honra póstuma me seja atribuída no meu país ou fora dele.”

Artigo recebido em 5/2006. Aprovado em 07/2006. 